\title{
16S ribosomal DNA sequencing confirms the synonymy of Vibrio harveyi and $V$. carchariae
}

\author{
Eric J. Gauger, Marta Gómez-Chiarri* \\ Department of Fisheries, Animal and Veterinary Science, 20A Woodward Hall, University of Rhode Island, Kingston, \\ Rhode Island 02881, USA
}

\begin{abstract}
Seventeen bacterial strains previously identified as Vibrio harveyi (Baumann et al. 1981) or V. carchariae (Grimes et al. 1984) and the type strains of V. harveyi, V. carchariae and V. campbellii were analyzed by $16 \mathrm{~S}$ ribosomal DNA (rDNA) sequencing. Four clusters were identified in a phylogenetic analysis performed by comparing a 746 base pair fragment of the 16S rDNA and previously published sequences of other closely related Vibrio species. The type strains of $V$. harveyi and $V$. carchariae and about half of the strains identified as V. harveyi or V. carchariae formed a single, wellsupported cluster designed as 'bona fide' V. harveyi/carchariae. A second more heterogeneous cluster included most other strains and the $V$. campbellii type strain. Two remaining strains are shown to be more closely related to $V$. rumoiensis and $V$. mediterranei. 16S rDNA sequencing has confirmed the homogeneity and synonymy of $V$. harveyi and $V$. carchariae. Analysis of API20E biochemical profiles revealed that they are insufficient by themselves to differentiate $V$. harveyi and $V$. campbellii strains. 16S rDNA sequencing, however, can be used in conjunction with biochemical techniques to provide a reliable method of distinguishing $V$. harveyi from other closely related species.
\end{abstract}

KEY WORDS: Vibrio harveyi · Vibrio carchariae - Vibrio campbellii · Vibrio trachuri · Ribosomal DNA $\cdot$ Biochemical characteristics $\cdot$ Diagnostic $\cdot$ API20E

\section{INTRODUCTION}

Vibrio harveyi (Baumann et al. 1981) and V. carchariae (Grimes et al. 1984) can cause disease in a large number of marine fish and shellfish species worldwide (Austin \& Austin 1999). V. harveyi, first isolated from a dead amphipod (Johnson \& Shunk 1936), can affect penaeid shrimp (Liu et al. 1996, Abraham et al. 1997, Alvarez et al. 1998, Robertson et al. 1998), rock lobster (Diggles et al. 2000) and salmonids (Zhang \& Austin 2000). V. carchariae, first identified by Grimes et al. (1984) has been shown to cause disease in elasmobranch species (Grimes et al. 1985), cephalopods (Hanlon \& Forsythe 1990), grouper Epinephelus coioides (Yii et al. 1997) and summer flounder Paralicthys dentatus (Soffientino et al. 1999). V. harveyi and $V$. carchariae are also ubiquitous in warm marine environments and have been isolated from a variety of

*Corresponding author. E-mail: gomezchi@uri.edu environmental sources (Ruby \& Morin 1979, Orndorff \& Colwell 1980, Feldman \& Buck 1984, Grimes et al. 1985, Grisez et al. 1997).

Until recently, Vibrio harveyi and V. carchariae have been accepted as closely related species that could, nonetheless, be distinguished by biochemical characteristics (Grimes et al. 1993, Alsina \& Blanch 1994) and 16S ribosomal RNA (rRNA) sequences (Kita-Tsukamoto et al. 1993, Ruimy et al. 1994, Soffientino et al. 1999). In contrast, a study by Pedersen et al. (1998) based on Amplified Fragment Length Polymorphisms (AFLP), DNA:DNA hybridization, and ribotyping found that the type strains of $V$. harveyi and $V$. carchariae were indistinguishable and should therefore be considered synonymous.

Here, we sought to investigate the discrepancies between classifications of Vibrio harveyi and V. carchariae based on different methods (16S rRNA sequencing, AFLP, ribotyping, DNA-DNA hybridization, biochemical characteristics). We describe the phyloge- 
netic relationship, based on 16S rDNA sequences, of the type strains of $V$. harveyi and $V$. carchariae, 17 putative V. harveyi and V. carchariae strains (Yii et al. 1997, Pedersen et al. 1998, Soffientino et al. 1999), and published 16S rDNA sequences of $V$. harveyi, V. carchariae and other closely related Vibrio spp. (Valle et al. 1990, Ruimy et al. 1994, Yumoto et al. 1999). Also, we compared 16S rDNA sequencing data to biochemical profiles. The implications for bacterial classification and diagnosis are discussed.

\section{MATERIALS AND METHODS}

Bacterial strains. Bacterial strains are listed in Table 1. The strains designated VIB 286, 295, 350, 394, 400, 403, 411, 570, 573, 645, 651, 654, 655, 656, 657, 660, and 697 belong to a collection maintained by Dr. Dawn Austin of Heriot-Watt University (Edinburgh, UK) (Pedersen et al. 1998). Also included in this study are a strain of Vibrio carchariae from grouper in Taiwan (Yii et al. 1997), designated here as $V$. carchariae grouper, a strain from summer flounder in the USA (Soffientino et al. 1999), designated here as V. carchariae flounder, and the type strains $\left({ }^{\mathrm{T}}\right.$ ) of $V$. harveyi (American Type Culture Collection, ATCC 14126 ${ }^{\mathrm{T}}$ ) and V. campbellii $\left(\right.$ ATCC $25920^{\mathrm{T}}$ ). VIB 286 is the designation given to the $V$. carchariae type strain in Pedersen et al. (1998). Throughout the text, the names VIB 286 and V. carchariae type strain are used interchangeably and refer to the same strain. VIB 295 is the designation given to the $V$. harveyi type strain by Pedersen et al. (1998). An additional sample of the $V$. harveyi type strain was obtained directly from ATCC (ATCC 14126 ${ }^{\mathrm{T}}$ ) and is referred to in the text as $V$. harveyi type strain.

Culture and biochemical profiles. Bacterial stock cultures were maintained in 15 to $20 \%$ (v/v) glycerol at $-70^{\circ} \mathrm{C}$. Active cultures were grown on Luria Bertani (LB) agar plates containing $20 \mathrm{~g} \mathrm{l}^{-1}$ of $\mathrm{NaCl}$ (LB 20) (Nelson et al. 1997) or LB 20 broth at $28^{\circ} \mathrm{C}$. Biochemical profiles were analyzed using API 20E strips (bioMérieux Vitek Inc.). Each strain was evaluated at least twice. One to 3 colonies from 24 to $48 \mathrm{~h}$ plate cultures, depending on growth rate, were resuspended in $5 \mathrm{ml}$ of $0.85 \%(\mathrm{w} / \mathrm{v}) \mathrm{NaCl}$ solution and vortexed. Sufficient bacteria was used to make a solution that was visibly turbid but not opaque. Strips were incubated at $28^{\circ} \mathrm{C}_{i}$ results were read at $48 \mathrm{~h}$ according to the manufacturer's instructions.

DNA extraction, amplification, and sequencing. Extraction of genomic DNA was accomplished by a modified version of a protocol by Medrano et al. (1990). Briefly, a single bacterial colony from a LB 20 plate was suspended in $550 \mu$ lysis buffer $(50 \mathrm{mM}$ Tris $\mathrm{HCl}$,

Table 1. Vibrio spp. Bacterial strains used for 16S rDNA sequencing and API20E analysis. LMG: Laboratorium voor Microbiologie, Rijksuniversiteit Gent, Belgium; CCUG: Culture Collection, University of Gothenburg, Göteborg, Sweden; ATCC: American Type Culture Collection, Rockville, MD, USA; NCIMB: National Collection of Industrial and Marine Bacteria, Aberdeen, Scotland, UK; HWU: Heriot-Watt University, Edinburgh, Scotland, UK; IP: Institut Pasteur, Paris, France; UB: Universitat de Barcelona, Spain; RVAU: Royal Veterinary and Agricultural University, Copenhagen, Denmark. ${ }^{\mathrm{T}}$ : type strain

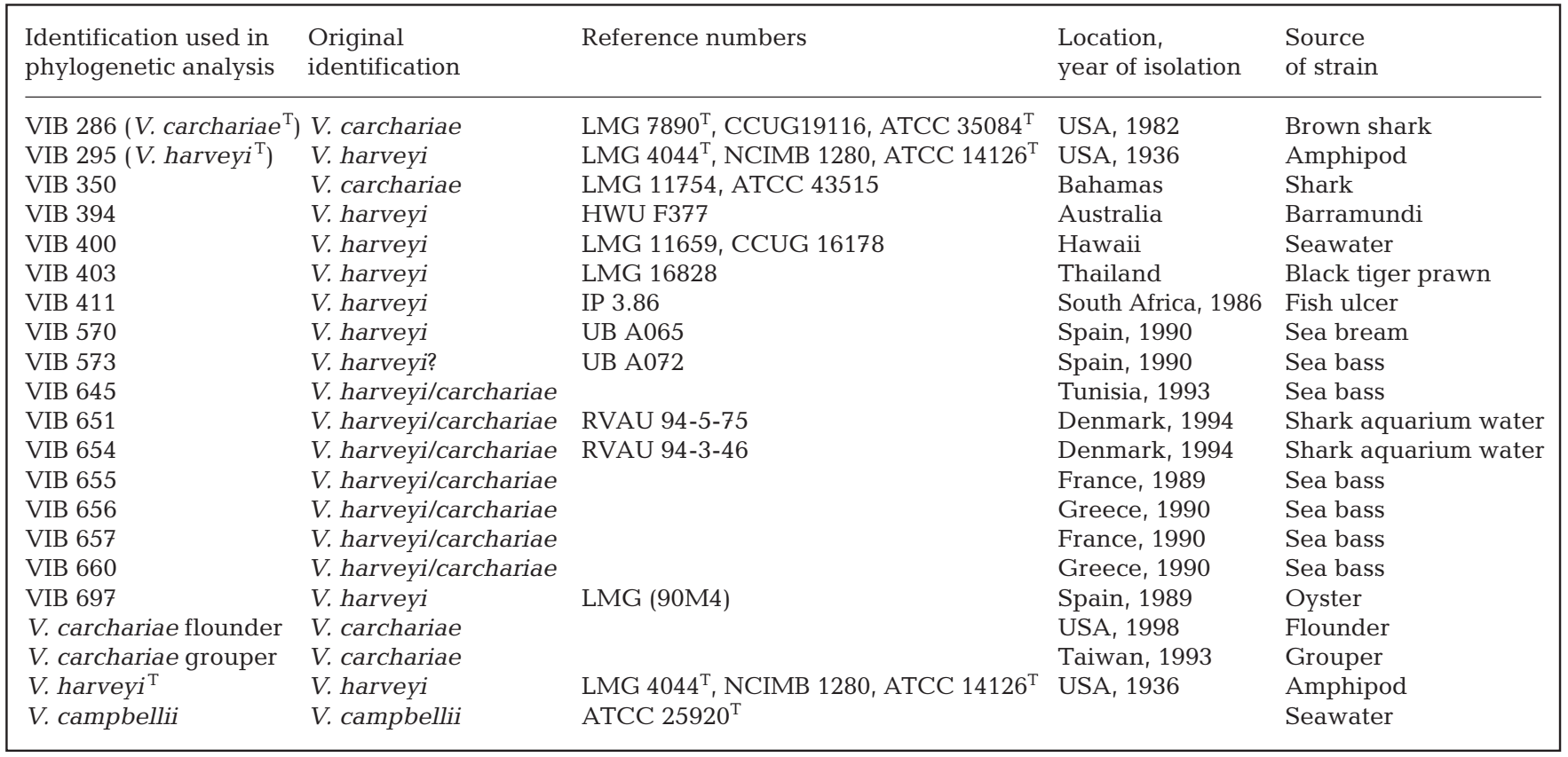


$20 \mathrm{mM}$ EDTA, $1 \%$ SDS, $200 \mathrm{mM} \mathrm{NaCl}, \mathrm{pH}$ 8.0) and $0.4 \mathrm{mg} \mathrm{ml}^{-1}$ Proteinase K in a microcentrifuge tube. This solution was incubated at $55^{\circ} \mathrm{C}$ until the cells lysed. $\mathrm{NaCl}$ was then added to a $2 \mathrm{M}$ final concentration and the solution was centrifuged (13400 $g$ for 30 min at room temperature). The aqueous portion was retained, DNA was ethanol precipitated, centrifuged (13400 g for $30 \mathrm{~min}$ at room temperature) and washed in $70 \%$ $(\mathrm{v} / \mathrm{v})$ ethanol. The resulting DNA was re-suspended in $50 \mu \mathrm{l}$ of $\mathrm{ddH}_{2} \mathrm{O}$ by incubation at $55^{\circ} \mathrm{C}$. DNA stocks were held at $-20^{\circ} \mathrm{C}$. Polymerase Chain Reaction (PCR) amplification was accomplished using Ready-To-Go PCR beads (Amersham-Pharmacia Biotech), approximately $100 \mathrm{ng}$ of genomic DNA, and $0.8 \mu \mathrm{M}$ oligonucleotide primers 13F (5'-TTGATCATGGCTCAGATTGATGAAGCG-3') and 1443R (5'-AACTACCTACTTCTTTTGCAGCCCACT-3'). Primer designations correspond to the 5' Escherichia coli positions (GenBank accession no. J01859). The amplification program consisted of an initial denaturation step of $5 \mathrm{~min}$ at $94^{\circ} \mathrm{C}$, followed by 36 cycles consisting of a $1 \mathrm{~min}$ denaturation step at $94^{\circ} \mathrm{C}$, a 2 min annealing step at $54^{\circ} \mathrm{C}$, and a 5 min elongation step at $72^{\circ} \mathrm{C}$. Four reactions were performed per strain. PCR products were run on a $0.7 \%(\mathrm{w} / \mathrm{v})$ agarose gel for $1 \mathrm{~h}$ along with a DNA molecular weight standard ladder to ensure a fragment of the proper length was observed. The fragments were cut from the gel and the DNA was extracted using a QIAquick column (Qiagen), following manufacturer's instructions. Prior to sequencing, quantification of the DNA was accomplished by an ethidium bromide spot method (Sambrook et al. 1989). Twenty-four $\mu \mathrm{l}$ sequencing reactions were prepared with approximately $100 \mathrm{ng}$ of template DNA and a $0.33 \mu \mathrm{M}$ concentration of either primer 637F (5'-TGAAACTGGCAGACTAGAG-3') or 1443R. Sequencing was performed at the HHMI Biopolymer Laboratory \& W. M. Keck Foundation Biotechnology Resource Laboratory (Yale University, New Haven, CT, USA) using an Applied Biosystems 377 slab gel and 3700 and 3100 capillary instruments. The sequencing reactions used fluorescently labelled dideoxynucleotides and Taq FS DNA polymerase in a thermal cycling protocol. The region corresponding to E. coli positions 637-1443 was chosen because it contained the majority of the sequence variations found between Vibrio harveyi X74706 and V. carchariae X74693 and could be covered effectively by a single sequencing reaction. Both strands of DNA were sequenced so that nucleotide uncertainties could be resolved. Sequences were submitted to GenBank (see below for accession numbers).

Phylogenetic analysis. The following sequences were used in the phylogenetic analysis: Vibrio harveyi type strain AF426825, V. campbellii type strain AF426824,
V. carchariae flounder AF426805, V. carchariae grouper AF426806, VIB 286 AF426814, VIB 295 AF426811, VIB 350 AF426813, VIB 394 AF426821, VIB 400 AF426816, VIB 403 AF426820, VIB 411 AF426823, VIB 570 AF426822, VIB 573 AF426817, VIB 645 AF426812, VIB 651 AF426815, VIB 654 AF426819, VIB 655 AF426807, VIB 656 AF426810, VIB 657 AF426809, VIB 660 AF426808, and VIB 697 AF426818. The following previously published sequences used in the phylogenetic analyses were obtained from GenBank: Aeromonas salmonicida X74681, V. alginolyticus X74690, V. campbellii X74692, V. carchariae X74693, V. cholerae classical X74695, V. cholerae Eltor X74694, V. mediterranei X74710, V. nereis X74716, V. ordalii X74718, and $V$. orientalis X74719 (Ruimy et al. 1994), Listonella (= Vibrio) anguillarum X16895 (Valle et al. 1990), V. rumoiensis AB013297 (Yumoto et al. 1999), and V. campbellii AY035896 (unpubl.). Sequences were aligned using the Clustal $\mathrm{W}$ program and pairwise genetic distances were determined using the ClustalDist program (Higgins et al. 1992) on the San Diego Super Computer Center's (SDSC) Biology Workbench (http://workbench.sdsc.edu). Alignments were checked manually. Groups of sequences that were found to be identical were treated as a single sequence for the remainder of the analysis. Aligned sequences were analyzed using PAUP version 4 (Swofford 1998). Bootstrap analysis (100 replicates) was performed using heuristic, neighbor-joining and Unweighted-Paired Grouping Mathematical Average (UPGMA) search algorithms, with the optimality criterion set to distance, codon positioning set to unknown, maximum number of trees saved set to 1000 and A. salmonicida X74681 set as the out group. Bootstrap analysis (100 replicates) was also performed with the optimality criterion set to maximum parsimony with all other settings identical to other search methods. Clusters found in this analysis were compared to the AFLP clusters found by Pedersen et al. (1998).

\section{RESULTS}

\section{Biochemical profiles}

API 20E strips were used to evaluate the biochemical profiles of the bacterial strains used in this study (Table 2). All strains were consistently positive for lysine decarboxylase, tryptophane deaminase, indole production, gelatinase, cytochrome-oxidase, and fermentation of glucose, mannitol, and amygdalin, and consistently negative for arginine dihydrolase, $\mathrm{H}_{2} \mathrm{~S}$ production, Vogues-Proskauer reaction, and fermentation of inositol, rhamnose, and arabinose. -galactosidase, ornithine decarboxylase, citrate utilization, urease, and the fermentation of sorbitol, sucrose, and 
Table 2. Vibrio spp. Selected API20E characteristics of bacterial strains. Strains are grouped according to sequence homology. V: variable result; $\mathrm{V}^{*}$ : - by API $20 \mathrm{E}_{\text {; }}$ + by Simmon's citrate slant. ONPG, ODC, CIT, URE, SOR, SAC, MEL correspond to -galactosidase, ornithine decarboxylase, citrate utilization, urease, and fermentation of sorbitol, sucrose, and melibiose, respectively

\begin{tabular}{|c|c|c|c|c|c|c|c|}
\hline \multirow[t]{2}{*}{ Bacterial strain } & \multicolumn{7}{|c|}{ API characteristic } \\
\hline & ONPG & ODC & CIT & URE & SOR & SAC & MEL \\
\hline V. harveyi ${ }^{\mathrm{T}}$ ATCC 14126 & - & + & + & - & - & + & - \\
\hline V. carchariae flounder & _- & + & + & $\mathrm{V}$ & + & + & _- \\
\hline V. carchariae grouper & - & + & + & + & _- & + & - \\
\hline VIB $286\left(\right.$ V. carchariae $\left.^{\mathrm{T}}\right)$ & - & V & $\mathrm{V}$ & V & - & + & - \\
\hline VIB $295\left(V \cdot\right.$ harveyi $\left.^{\mathrm{T}}\right)$ & - & + & $\mathrm{V}$ & $\mathrm{V}$ & - & $\mathrm{V}$ & $\mathrm{V}$ \\
\hline VIB 411 & - & - & $\mathrm{V}$ & - & _- & + & - \\
\hline VIB 570 & - & + & + & + & + & + & - \\
\hline VIB 573 & _ & + & $\mathrm{V}$ & _- & + & _- & _ \\
\hline VIB 645 & _- & + & + & + & + & + & _- \\
\hline VIB 651 & - & + & + & - & + & + & - \\
\hline VIB 654 & - & + & $\mathrm{V}$ & $\mathrm{V}$ & - & + & - \\
\hline VIB 660 & - & + & + & + & + & + & - \\
\hline V. campbellii ${ }^{\mathrm{T}}$ ATCC 25920 & 0 & - & - & - & - & - & - \\
\hline VIB 655 & _- & + & $\mathrm{V}^{*}$ & + & _- & + & - \\
\hline VIB 656 & - & + & - & - & - & + & - \\
\hline VIB 657 & - & + & $\mathrm{V}^{*}$ & - & - & - & - \\
\hline VIB 403 & + & + & $\mathrm{V}^{*}$ & + & _- & _- & _- \\
\hline VIB 697 & - & + & - & - & - & - & - \\
\hline VIB 394 & - & + & - & - & - & - & - \\
\hline VIB 350 & + & - & - & - & + & + & V \\
\hline VIB 400 & + & + & - & - & - & + & - \\
\hline
\end{tabular}

melibiose showed some degree of variability among the strains examined.

\section{Sequence alignments and genetic distances}

Sequence variations were observed at positions 976 , 1003-1009, 1015-1021, 1131-1140, 1256-1261，1264， 1269, 1307, and 1318. The most variable region is located from positions 1131 to 1140 , where 1 of 2 sequence motifs is observed (Table 3 ). The first sequence motif, ACTTCGGGT-, is found in strains VIB 295, 411, 570, 573, 645, 651, 654, 660, Vibrio carchariae flounder, $V$. carchariae grouper, and the type strains of $V$. harveyi and $V$. carchariae. Among these strains there are only minor differences elsewhere, with the sequences for the type strains of $V$. harveyi (VIB 295 and ATCC $14126^{\mathrm{T}}$ ) and $V$. carchariae (VIB 286) being identical. These sequences were found to be distinctly different from the sequence reported by Ruimy et al. (1994) for the same $V$. harveyi strain, ATCC $14126^{\mathrm{T}}$ (X74706).

The second sequence motif, GAGTAAT GTC, is observed in strains VIB 350, 394, 400, 403, 655, 656, 657, 697, and the Vibrio campbellii type strain (ATCC 25920), differing from the first group in 7 of the 10 base pairs (bp) in this region. In this group a greater degree of sequence heterogeneity is seen in other regions that can be used as the basis of further sub-divisions.

Pairwise genetic distances for the 21 strains listed in Table 1 and the 13 reference strains listed previously are shown in Table 4. Strains VIB 411, 570, 573, 645, 651, 654, 660, Vibrio carchariae flounder and V. carchariae grouper were identical or nearly identical to our sequences of the type strains of $V$. harveyi (VIB 295 and ATCC $14126^{\mathrm{T}}$ ) and V. carchariae (VIB 286). Strains VIB 394, 403, 655, 656, 657, and 697 were more similar to previously reported sequences of $V$. campbellii (X74692, AY035896). VIB 350 and VIB 400 were nearly identical to the previously published sequences of $V$. mediterranei (X74710), and V. rumoiensis (AB013297) respectively.

Table 3. Vibrio spp. Abbreviated sequence alignments. Variations from $V$. harveyi/V. carchariae type strain sequences are in boldface. Strains listed in the same row have identical sequences in the region investigated

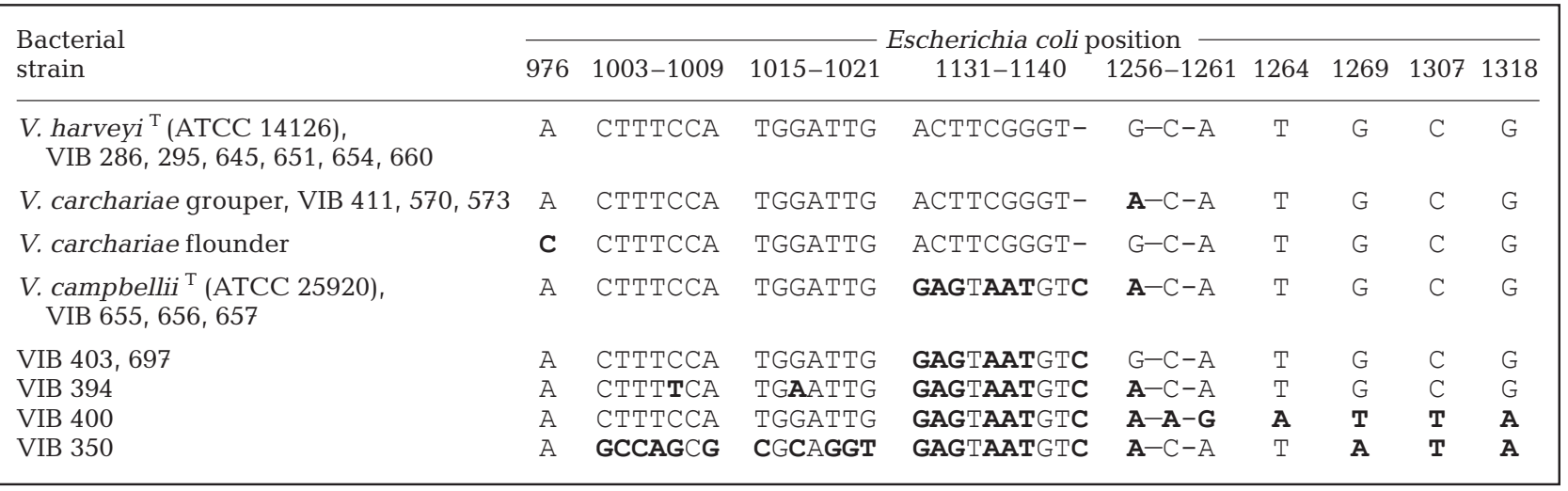




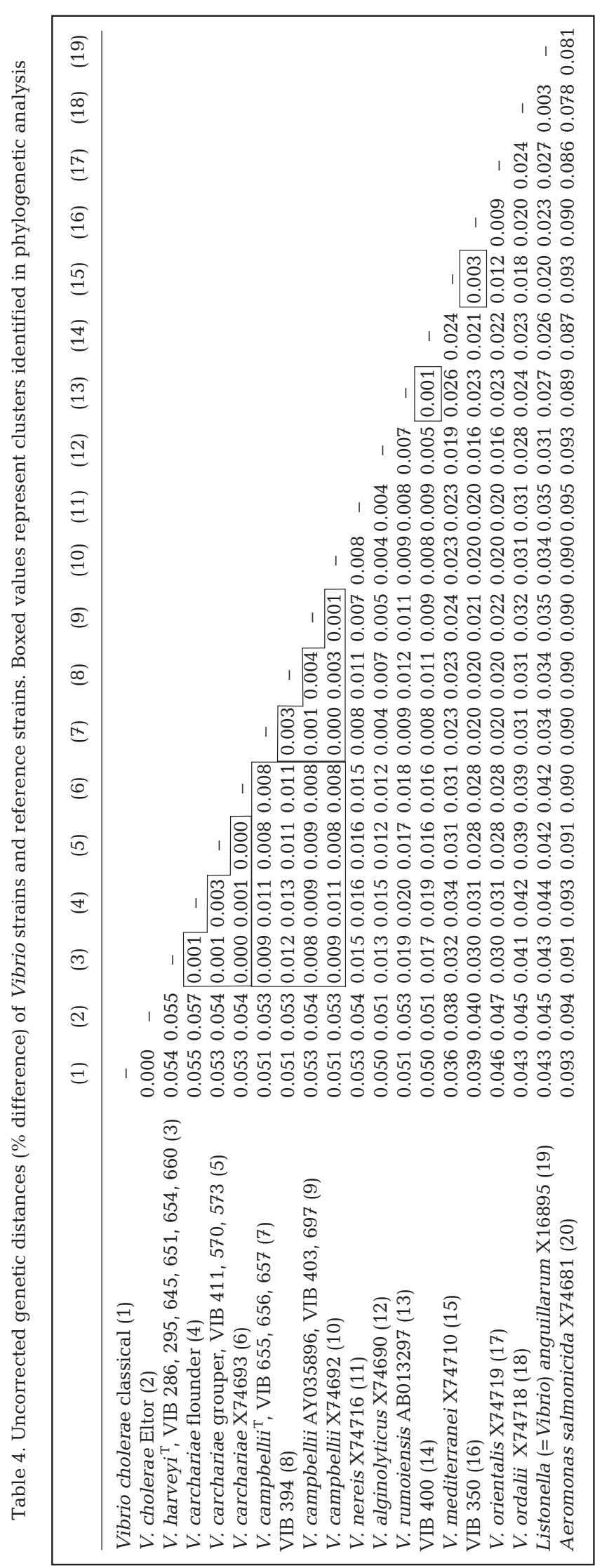

\section{Phylogenetic analysis}

Phylogenetic analysis is based on a 746 bp region covering positions 642-1387 in the Escherichia coli sequence (J01859) for which sequence data was obtained for all 21 strains investigated for this study as well as the 13 reference sequences obtained from GenBank. An unrooted tree constructed using the UPGMA method is shown in Fig. 1. Other trees constructed using the neighbor-joining and heuristic search methods as well as the maximum parsimony method gave similar results (not shown). The bulk of the strains investigated for this study form a large, well-supported group that includes previously published sequences of Vibrio carchariae, V. alginolyticus, V. campbellii, V. nereis, and $V$. rumoiensis (Fig. 1). Within this group the type strains of $V$. carchariae and V. harveyi, the V. carchariae isolated from summer flounder in the USA, the $V$. carchariae from grouper in Taiwan and vibrios isolated from aquarium seawater in Denmark and disease outbreaks in fish from South Africa and the Mediterranean (VIB 411, 570, $573,645,651,654)$, along with the reference strain $V$. carchariae X74693, form a strongly supported cluster (Cluster 1 in Fig. 1). This cluster contains all the strains belonging to AFLP cluster 1 (Pedersen et al. 1998) that were included in the present study and is considered the 'bona fide' $V$. harveyi cluster. Strains from prawn in Thailand, barramundi in Australia, oyster in Spain and sea bass in the Mediterranean (VIB 403, 394, 697, 655, and 656) belonging to AFLP Clusters 4, 5, and 7 and VIB 657 (AFLP unclustered) form a less well-supported cluster designated as Cluster 2 (Fig. 1) with the V. campbellii type strains (AF426824 and X74692) and a previously reported sequence of $V$. campbellii (AY035896, unpubl.). In fact, only the UPGMA method places all of these strains in 1 cluster (bootstrap value $=72 \%$ ). Neighborjoining and heuristic methods maintain the grouping of V. campbellii type strain (AF426824) and VIB 655, 656, and 657 with $V$. campbellii X74692 (average bootstrap value $=66 \%$ ) but exclude VIB 394, 403, and 697 and $V$. campbellii AY035896. The maximum parsimony method does not group any of these strains together. Despite the low tendency of these strains to cluster together it should be noted that there are no more than $2 \mathrm{bp}$ differences between any member of this group and the $V$. campbellii type strain. The $16 \mathrm{~S}$ sequences of 2 other strains (VIB 350 and VIB 400), originally identified as $V$. harveyi, were also found to be distinctly different from the $V$. harveyi cluster (Cluster 1 Fig. 1), and match more closely with sequences corresponding to other Vibrio spp. VIB 400 (AFLP Cluster 3), a bacterium isolated from seawater in Hawaii, is shown in all phylogenetic analyses to be more closely related to $V$. rumoiensis (Cluster 3, Fig. 1). VIB 350 (AFLP Cluster 9), isolated from a shark from the Bahamas, was found to be most closely related 


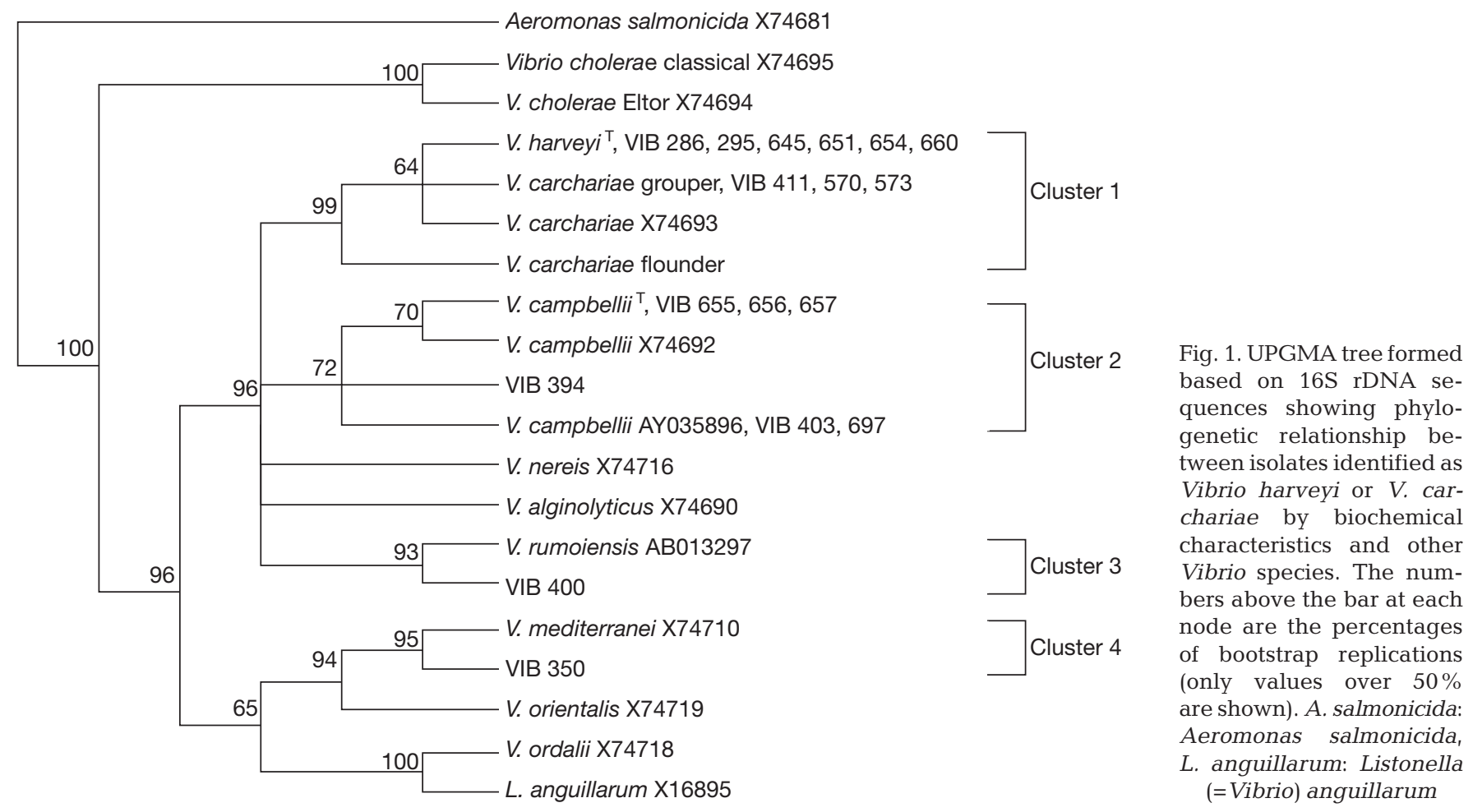

to $V$. mediterranei (X74710) and also clusters closely with V. orientalis (X74719) (Cluster 4, Fig. 1).

\section{DISCUSSION}

Pedersen et al. (1998) found that Vibrio harveyi and $V$. carchariae could not be distinguished by molecular means (AFLP, DNA-DNA hybridization, ribotyping) and should therefore be considered synonymous. Previously published $16 \mathrm{~S}$ rDNA sequences of $V$. harveyi and $V$. carchariae, however, had substantial differences (Ruimy et al. 1994, Soffientino et al. 1999), contradicting the molecular evidence found by Pedersen et al. (1998). Our analysis of $16 \mathrm{~S}$ rDNA sequences focused on a 746 bp region that covers the area in which the majority of differences in the sequences of $V$. harveyi and V. carchariae were previously found (Ruimy et al. 1994). Our findings indicate that the partial 16S rDNA sequences for the type strains of $V$. harveyi and $V$. carchariae that were shown to be different by Ruimy et al. (1994) are in fact identical. Furthermore, sequences for all isolates belonging to the 'bona fide' $V$. harveyi AFLP cluster (Pedersen et al. 1998), as well as the V. carchariae grouper and $V$. carchariae flounder isolates and reference strain $V$. carchariae X74693, were identical or nearly identical to sequences for the $V$. harveyi and $V$. carchariae type strains. In our phylogenetic analysis, these isolates clustered together with high bootstrap values. We find, therefore, that $16 \mathrm{~S}$ rDNA sequencing confirms the finding by Pedersen et al. (1998) that $V$. harveyi and $V$. carchariae are synonymous.

Recently, Thompson et al. (2002) showed that Vibrio trachuri, a pathogen of the Japanese horse mackerel Trachurus japonicus, is also a synonym of $V$. harveyi based on DNA:DNA hybridization, AFLP, biochemical tests, and mol \% G+C content. The $16 \mathrm{~S}$ rDNA sequence of $V$. trachuri reported in Thompson et al. (2002) (AJ312382) is $100 \%$ similar to the sequence of the $V$. harveyi type strain reported here (AF426825). This further strengthens the conclusion of Thompson et al. (2002) that $V$. trachuri is a synonym of $V$. harveyi.

Vibrio harveyi and $V$. carchariae show a high degree of heterogeneity in their biochemical characteristics (Grimes et al. 1993, Alsina \& Blanch 1994). This is not unexpected; biochemical properties are often highly variable for environmental and pathogenic strains (Alsina \& Blanch 1994). When the strains included in the current study are grouped according to sequence homology (see Table 1), no API 20E characteristic can be used to effectively differentiate strains corresponding to all the clusters found in Fig. 1. Although more complete biochemical characterizations have been proposed to differentiate closely related Vibrio spp. (Bryant et al. 1986, Grimes et al. 1993, Alsina \& Blanch 1994) they may be unreliable due to variability in biochemical traits and the possibility of errors in the interpretation of test results. The high number of tests required may also make them impractical. The weakness of using biochemical profiles as the sole means of iden- 
tifying bacterial isolates is evidenced by our finding that 8 of 15 putative $V$. harveyi isolates in the Pedersen study had 16S rDNA sequences that match more closely to other Vibrio species. This suggests that biochemical analysis, by itself, may not be the most reliable method of distinguishing $V$. harveyi from other closely related species, particularly $V$. campbellii.

Molecular tools such as AFLP, DNA:DNA hybridization, and 16S rDNA sequencing have proven to be useful tools for classification and identification of bacterial species (Busse et al. 1996, Kolbert \& Persing 1999). One advantage of 16S rDNA sequencing is that it is accessible to any laboratory with technical skills in PCR because, thanks to the Human Genome Project, fast and reliable automated sequencing is now available to researchers at a relatively affordable price. Computer applications such as BLAST (Altschul et al. 1990) can be used to search databases like GenBank and EMBL, allowing preliminary identifications without needing to include large numbers of reference strains in the study. With AFLP and DNA:DNA hybridization, comparisons can only be made with the bacterial strains on hand. Among the limits of $16 \mathrm{~S}$ rDNA sequencing are the potential for DNA contamination in PCR reactions and the presence of conflicting or erroneous sequences deposited in the databases (Kolbert \& Persing 1999, Macián et al. 2000), as is apparently the case for the 16S rDNA sequence of the Vibrio harveyi type strain (X74706) reported by Ruimy et al. (1994). Errors such as this can be caused by the difficulties of older (manual) methods of sequencing or simply by assigning a sequence to a strain incorrectly. The exponential increase in accurate sequencing information should help minimize these problems. Another significant weakness of $16 \mathrm{~S}$ sequencing as a diagnostic method is the possibility of 2 distinct species sharing identical or nearly identical 16S rDNA sequences (Kolbert \& Persing 1999).

In this study, we find agreement between data from 16S rDNA sequencing and other molecular means when identifying Vibrio harveyi and V. carchariae isolates. Isolates belonging to the 'bona fide' $V$. harveyi AFLP cluster also clustered together on the basis of 16S rDNA sequence homology. The delineation of other clusters based on 16S rDNA also generally agreed with AFLP clusters; however, certain discrepancies were apparent. Strains that clustered with $V$. campbellii on the basis of 16S rDNA sequences (VIB 394, 403, 655, 656, 657, and 697) were spread among 3 AFLP clusters with only 1 strain (VIB 697) located in the same AFLP cluster as the V. campbellii type strain (see Fig. 1). It is uncertain if these strains represent distinct species with very similar 16S rDNA sequences or if AFLP analysis simply detected heterogeneities beyond the species level. One other anomalous result was that VIB 350 clustered with the type strain of $V$. alginolyticus on the basis of AFLP patterns but was shown to be more similar to $V$. mediterranei by $16 \mathrm{~S}$ rDNA sequencing. Pedersen et al. (1998) noted that this strain clearly clustered with other $V$. harveyi and $V$. carchariae strains in its original description (Grimes et al. 1993) and therefore doubted the authenticity of their subculture of this strain (Pedersen et al. 1998). Based on our analysis of current sequence databases, and general agreement with other molecular methods of identification, 16S rDNA sequencing appears to be a reliable method of identifying $V$. harveyi.

As suggested by Busse et al. (1996), a good strategy for the accurate identification of bacteria is to use a 'polyphasic' approach that might begin with sequencing a fragment of the 16S rRNA gene. Information obtained by the sequence analysis will provide clues on which genotypic and phenotypic methods will be most suitable to confirm the identification of a previously described species or for a more complete description of a new species. In the case of Vibrio harveyi, 16S rDNA sequencing can provide a relatively certain identification. A standard biochemical profile system such as the API 20E can be used to confirm the sequence-based identification and prevent the incorrect identification of unknown or not previously sequenced species that share highly similar 16S rRNA sequences.

In conclusion, 16S rDNA sequencing has confirmed the homogeneity and synonymy of Vibrio harveyi, $V$. carchariae, and V. trachuri, and indicated errors in the GenBank database with regard to $V$. harveyi (X74706). $V$. harveyi therefore emerges as a major bacterial pathogen, capable of infecting a wide range of species including penaeids (Liu et al. 1996, Abraham et al. 1997, Alvarez et al. 1998, Robertson et al. 1998), bivalves (Pass et al. 1987), cephalopods (Hanlon \& Forsythe 1990), teleosts (Yii et al. 1997, Soffientino et al. 1999, Zhang \& Austin 2000, Thompson et al. 2002) and elasmobranchs (Grimes et al. 1985). As such, it is likely that $V$. harveyi will be isolated from an increasing number of fish and shellfish species. The use of 16S rDNA sequencing in conjunction with the biochemical characteristics should provide a more accurate and efficient method of diagnosing $V$. harveyi and other related species than extensive biochemical profiling alone.

Acknowledgements. The authors wish to thank Dr. Dawn Austin for providing most of the bacterial strains used in this study and Dr. Brian Austin for his extremely useful comments in the preparation of the manuscript. We thank Dr. Yii for providing the $V$. carchariae strain isolated from grouper in Taiwan. Finally we wish to acknowledge HHMI Biopolymer Laboratory \& W. M. Keck Foundation Biotechnology Resource Laboratory at Yale University for performing the DNA sequencing for this study. This research was supported by the Rhode Island Agriculture Experiment Station, grant number H401 (Contribution number 3952). 


\section{LITERATURE CITED}

Abraham TJ, Manley R, Palanippan R, Dhevendaran K (1997) Pathogenicity and antibiotic sensitivity of luminous $V$. harveyi isolated from diseased penaeid shrimp. J Aquacult Trop 12:1-8

Alsina M, Blanch AR (1994) A set of keys for biochemical identification of environmental Vibrio species. J Appl Bacteriol 76:79-85

Altschul SF, Gish W, Miller W, Myers EW, Lipman DJ (1990) Basic local alignment search tool. J Molec Biol 215: $403-410$

Alvarez JD, Austin B, Alvarez AM, Reyes H (1998) Vibrio harveyi: a pathogen of penaeid shrimps and fish in Venezuela. J Fish Dis 21:313-316

Austin B, Austin DA (1999) Characteristics of the pathogens: Gram-negative bacteria, Vibrionaceae representatives. In: Laird S, Stead S (eds) Bacterial fish pathogens: disease of farmed and wild fish, 3rd rev. edn. Springer-Praxis, Chichester, p 102-118

Baumann P, Baumann L, Bang SS, Woolkallis MJ (1981) Reevaluation of the taxonomy of Vibrio, Beneckea and Photobacterium: abolition of the genus Beneckea. Curr Microbiol 4:127-132

Bryant TN, Lee JV, West PA, Colwell RR (1986) A probability matrix for the identification of species of Vibrio and related genera. J Appl Bacteriol 61:469-480

Busse HJ, Denner, EB, Lubitz W (1996) Classification and identification of bacteria: current approaches to an old problem. Overview of methods used in bacterial systematics. J Biotechnol 47:3-38

Diggles BK, Moss GA, Carson J, Anserson CD (2000) Luminous vibriosis in rock lobster Jasus verreauxi (Decapoda: Palinuridae) phyllosoma larvae associated with infection by Vibrio harveyi. Dis Aquat Org 43:127-137

Feldman KA, Buck JD (1984) Distribution and characterization of luminescent bacteria in a temperate estuary. Estuaries 7:93-97

Grimes DJ, Colwell RR, Stemmler J, Hada H and 5 others (1984) Vibrio species as agents of elasmobranch disease. Helgol Wiss Meeresunters 37:309-315

Grimes DJ, Brayton P, Colwell RR, Ruber SH (1985) Vibrios as autochthonous flora of neritic sharks. Syst Appl Microbiol 6:221-226

Grimes DJ, Jacobs D, Swartz DG, Brayton P, Colwell RR (1993) Numerical taxonomy of Gram-negative, oxidasepositive rods from carcharid sharks. Int J Syst Bacteriol 43:88-98

Grisez L, Reyniers J, Verdonck L, Swings J, Ollevier F (1997) Dominant intestinal microflora of sea bream and sea bass larvae, from two hatcheries, during larval development. Aquaculture 155:391-403

Hanlon RT, Forsythe JW (1990) Diseases of mollusca: Cephalopoda. In: Kinne O (ed) Diseases of marine mammals, Vol III. Biologische Anstalt Helgoland, Hamburg, p 21-43

Higgins DG, Bleasby AJ, Fuchs R (1992) CLUSTAL V: improved software for multiple sequence alignment. Comput Appl Biosci 8:189-192

Johnson FH, Shunk IV (1936) An interesting new species of luminous bacteria. J Bacteriol 31:585-592

Kita-Tsukamoto K, Oyaizu H, Nanba K, Simidu U (1993) Phylogenetic relationships of marine bacteria, mainly members of the family Vibrionaceae, determined on the basis of 16S rRNA sequences. Int J Syst Bacteriol 43:8-19

Kolbert CP, Persing DH (1999) Ribosomal DNA sequencing as a tool for identification of bacterial pathogens. Curr Opin Microbiol 2:299-305

Liu PC, Lee KK, Chen SN (1996) Pathogenicity of different isolates of $V$. harveyi to tiger prawns, Penaeus monodon. Lett Appl Microbol 22:413-416

Macián, MC, Wolfgang L, Schleifer KH, Esperanza G, Pujalte MJ (2000) Vibrio pelagius: differences of the type strain deposited at various culture collections. Syst Appl Microbiol 23:373-375

Medrano JF, Aasen E, Sharrow L (1990) DNA extraction from nucleated red blood cells. Biotechniques 8:43-43

Nelson DR, Sadlowski Y, Eguchi M, Kjelleberg S (1997) The starvation-stress response of Vibrio (Listonella) anguillarum. Microbiology 143:2305-2312

Orndorff SA, Colwell RR (1980) Distribution and identification of luminous bacteria from the Sargasso Sea. Appl Environ Microbiol 39:983-987

Pass DA, Dybdahl R, Mannion MM (1987) Investigations into the causes of mortality of the pearl oyster, Pinctada maxima (Jamson), in Western Australia. Aquaculture 65: 149-169

Pedersen K, Verdonck L, Austin B, Austin DA and 8 others (1998) Taxonomic evidence that Vibrio carchariae Grimes et al. 1985 is a junior synonym of Vibrio harveyi (Johnson and Shunk 1936) Baumann et al 1981. Int J Syst Bacteriol 48:749-758

Robertson PAW, Calderon J, Carrera L, Stark JR, Zherdmant M, Austin B (1998) Experimental Vibrio harveyi infections in Penaeus vannamei larvae. Dis Aquat Org 32:151-155

Ruby EG, Morin JG (1979) Luminous enteric bacteria of marine fishes: a study of their distribution, densities, and dispersion. Appl Environ Microbiol 38:406-411

Ruimy R, Breittmayer V, Elbaze P, Lafay B, Boussemart O, Gauthier M, Christen R (1994) Phylogenetic analysis and assessment of the genera Vibrio, Photobacterium, Aeromonas, and Plesiomonas deduced from small-subunit rRNA sequences. Int J Syst Bacteriol 44:416-426

Sambrook J, Fritsch EF, Maniatis T (1989) Molecular cloning. A laboratory manual. Cold Spring Harbor Laboratory Press Cold Spring Harbor, NY, p E.5-E.7

Soffientino B, Gwaltney T, Nelson DR, Specker JL, Mauel M, Gómez-Chiarri M (1999) Infectious necrotizing enteritis and mortality caused by Vibrio carchariae in summer flounder Paralichthys dentatus during intensive culture. Dis Aquat Org 38:201-210

Swofford DL (1998) PAUP* phylogenetic analysis using parsimony ( ${ }^{*}$ and other methods) Ver 4. Sinauer Associates, Sunderland

Thompson FL, Hoste B, Vandemeulebroecke K, Denys R, Swings J (2002) Vibrio trachuri Iwamoto et al. 1995 is a junior synonym of Vibrio harveyi (Johnson and Shunk 1936) Baumann et al. 1981. Int J Syst Evol Microbiol 52:973-976

Valle O, Dorsch M, Wiik R, Stackebrandt E (1990) Nucleotide sequence of the 16S rRNA from Vibrio anguillarum. Syst Appl Microbiol 13:257-257

Yii KC, Yang TI, Lee KK (1997) Isolation and characterization of Vibrio carchariae, a causative agent of gastroenteritis in the groupers, Epinephelus coioides. Curr Microbiol 35: 109-115

Yumoto I, Iwata H, Sawebe T, Ueno K, Ichise N, Matsuyama H, Okuyama H, Kawasaki K (1999) Characterization of a facultatively psychrophilic bacterium, Vibrio rumoiensis sp. nov., that exhibits high catalase activity. Appl Environ Microbiol 65:67-72

Zhang XH, Austin B (2000) Pathogenicity of Vibrio harveyi to salmonids. J Fish Dis 23:93-102

Submitted: February 12, 2002; Accepted: June 7, 2002

Proofs received from author(s): August 27, 2002 